\title{
23
}

\section{THE LINK BETWEEN ICT AND ECONOMIC GROWTH IN THE DISCOURSE OF DEVELOPMENT}

\author{
Chrisanthi Avgerou \\ London School of Economics, UK.
}

\begin{abstract}
In this paper, I examine the validity of the relationship between ICT and economic development that has been constructed in the discourse of some influential international development organizations. I argue that the tool-andeffect association suggested in such discourse is dubious and misleading. It is based on narrow economic theory and ignores both the controversies that surround it and empirical evidence of alternative development policies. I point out that the policy analyses and recommendations of major development organizations influence the interventions of information systems professionals in developing countries with misguided perceptions and prescriptions that stifle the undertaking of situated efforts to put ICT to effective use.
\end{abstract}

Keywords: Economic development, economic growth, economic theory, economic policy, ICT and development.

\section{INTRODUCTION}

A striking feature of the world at the beginning of the $21^{\text {st }}$ century is the gross inequalities between the socio-economic conditions of different communities. The most visible of these relate to the world development problem of inequalities among nations. Contemporary discourses on development consistently identify ICT as a requirement for economic growth and the improvement of social conditions. Strictly speaking, this is not a new discourse; ever since the advent of computers, government policy advisors and international development agencies have pointed to the opportunities the technology opens for development. More recently, however, the link between ICT and development has been articulated in the 
alarming terms of the 'digital divide'. There is concern that developing countries are deprived of the opportunities for economic growth and life improvement generally enjoyed by advanced economies because of the scarcity of ICT, particularly limited Internet connectivity.

The lack of ICT is understood to be an important factor contributing to the widening of the gap between 'developed' and 'developing' countries, as shown by world socio-economic indicators published in the annual reports of international development agencies, such as those from the World Bank and the United Nations Development Programme (UNDP) discussed later in this paper. Many high profile initiatives have been undertaken to remedy this problem. They typically aim to create awareness on the benefits of ICT, raise investment, and promote policy measures for the deployment of telecommunications infrastructures and the diffusion of ICT applications in all societal sectors. Notable examples of these projects include the Digital Opportunity Task Force of the eight major industrial nations, G-8 (Dot force initiative, http://www.dotforce.org), the World Summit for the Information Society of the United Nations and the International Telecommunications Union (WSIS initiative, http://www.itu.int/wsis) and the World IT Forum of the International Federation of Information Processing (WITFOR programme, http://www.witfor.lt).

For many information systems scholars and professionals, such a general association of ICT with socio-economic effects is of questionable validity. It is well understood in information systems studies that the actual 'effects' of ICT in the place where it is used cannot be identified in terms of the potential of the new technologies as manifested in the laboratory or as realized in other social settings. ICT innovation is a process that takes place within the formative conditions of a particular social and organizational context (Suchman, 1987; Ciborra and Lanzara, 1994; Avgerou, 2002a). With specific reference to the question of ICT and development, the literature on information systems in developing countries includes a substantial amount of empirical evidence, mainly case studies, that reveals the situated manner in which information systems projects take shape within communities striving to improve their life conditions - see, for example, the publications of past IFIP 9.4 conferences (Bhatnagar and Bjorn-Andersen, 1990; Bhatnagar and Odedra, 1992; Odedra-Straub, 1996; Avgerou and Walsham, 2000; Sahay, 2000; Krishna and Madon, 2002). At the organizational level of analysis, information systems researchers and professionals are well aware of the tension between the situated nature of the course of change and general, apparently rational, theoretical propositions on the way ICT impacts - or should impact - on organizational performance.

Nevertheless, the discourse of international development agencies on the role of ICT merits attention in information systems research because it 
constitutes part of the institutional context of the micro-level processes involved in the formation of information systems (Avgerou, 2002b). This discourse influences the legitimacy of professional interventions towards specific objectives and sensitizes 'users' to a particular view of the way ICT may affect their lives. The current emphasis on the digital divide as the major contemporary problem facing developing countries also determines the way the meaning of ICT-based information systems is understood in universalist terms. It conveys specific views on why Internet connectivity is important and what it should achieve for even the remotest communities of the world. For example, interventions to develop community ICT services in poor regions bear implicit promises for economic benefits through participation in the global market and for rationalized citizens/government interactions. Moreover, there is a tendency to see such ICT centres as sustainable businesses in their own right (Best and Maclay, 2002). In other words, a universalist discourse on ICT and development constructs and spreads in developing countries specific development visions of new, technology-mediated modern lives.

In this paper, I examine the relationship between ICT and economic development in four recent influential publications: UNDP's 2001 Human Development Report, Making New Technologies Work for Human Development (United Nations Development Programme, 2001); the 2002 World Development Report, Building Institutions for Markets, of the World Bank (2002); and two publications by the Center for International Development at Harvard University, The Global Information Technology Report: Readiness for the Networked World (Kirkman et al., 2002), and The Global Competitiveness Report 2001-2002 (Porter et al., 2002a).

All these publications propose ICT as an instrument for economic and social gains within a market regime, and they elaborate on the conditions under which ICT plays this kind of developmental role. The central issue in the discourse in these texts concerns the socio-economic conditions that are favorable for the mutual re-enforcement of ICT innovation and an effective market. To examine the logic underlying the suggested conditions, I then look briefly at the theories that inform these documents and the controversies surrounding them. I conclude by arguing that the tool-andeffect link between ICT and economic development exemplified in these publications is dubious. My contention is that such a link is based on a narrow economic perspective of human action which ignores recent socioeconomic theory of development and is not informed by the evidence on processes of development that has emerged from the few countries which achieved substantial economic growth in the last decades of the $20^{\text {th }}$ century. 


\section{EXAMPLES OF THE DISCOURSE ON ICT AND DEVELOPMENT}

UNDP's 2001 Human Development Report (United Nations Development Programme, 2001) is a good example of the association international organizations make between ICT and development, not least because this series of UNDP reports takes a broad view of development as a socio-economic condition that goes beyond a narrow consideration of economic growth. The 2001 UNDP report seeks to present a clear association between technology and desirable development effects, giving special attention to ICT - particularly the Internet. Indicatively, it quotes a World Bank study (Preker et al., 1999) that showed 'technical progress accounted for $40-50 \%$ of mortality reductions between 1960 and 1990 making technology a more important source of gains than higher incomes or higher education levels among women' (ibid.: p.29). The UNDP report asserts that, '(c)ross-country studies suggest that technological change accounts for a large portion of differences in growth rates' (ibid.).

More importantly, this report attempts to qualify how technology, especially ICT, is 'enabling' development effects. The association between technology and human development is presented as follows. Technological innovation enhances human capabilities - such as a healthy life, knowledge, creativity, and participation in the social, economic, and political life of a community - and impacts on economic growth through productivity gains. At the same time, human capabilities are an important means for achieving technological innovation. Therefore, technology innovation and development are 'mutually reinforcing, creating a virtuous circle' (ibid.: p.28).

This 'virtuous circle' model is a significant step towards tracing the dynamic relationship of technology innovation and development, which goes beyond the static association of ICT diffusion and growth rates. Nevertheless, the UNDP report chooses to elaborate mainly on the argument that ICT innovation achieves developmental goals, thus retaining and cultivating a view of an instrumental relationship between the means of 'technological advance' and the desirable effect of 'human development'. Although the authors of the report explicitly recognize that technology may well be 'a reward of development', rather than being a tool for development, they are keen to dismiss this interpretation and assure readers that 'technology is a tool for, not just a reward of, growth and development' (ibid.: p.27).

This indicates a need to take a closer look at the reasoning that sustains the tool-and-effect association of ICT and development, in order to help answer the question: How is ICT understood to contribute to the process of 
economic development? For this, relevant explanatory insights are provided by the two recent publications of the Center for International Development at Harvard University mentioned in the previous section.

The report on the 'networked world' begins with the statement that 'the Internet and other ICTs have fundamentally changed the way the world works' (Kirkman et al., 2002). It then sets out to analyse, understand, and measure the link between ICT and development, with a particular focus on the issues of developing countries. The economic reasoning of its premise on the role of ICT in the development process is that the technology enhances the functioning of the markets because it provides information to producers and consumers in order to help them make efficient choices (Eggleston et al., 2002).

Kirkman et al. (ibid.) propose a framework of factors contributing to a country's capacity to exploit the opportunities offered by ICT. On the basis of this framework, their report derives the 'Networked Readiness Index' and ranks 75 countries on it. This index is composed of (a) measurements of the diffusion of the Internet and other ICT components and (b) assessments of a number of factors considered to be preconditions for high quality use of the Internet and its further proliferation and application. Important factors to that end identified by the authors of the report include: infrastructures for network access; the level of competition in the economy, particularly in the telecommunications and ICT sectors; social conditions, such as education level and the incorporation of ICT in education; and the extent to which ICT has been incorporated into business and government activities.

In this analysis, the market is the mechanism through which ICT is associated with economic development. In effect, this report identifies the virtuous circle process more specifically in terms of ICT and an effective market regime. But the relationship between ICT and market-driven development is presented in a self-referential way. The existing capacity of ICT in the socio-economic fabric is considered a condition of 'readiness' for further ICT development through network-based activities. The diffusion of ICT in all sectors of the economy and society, together with the liberalization of the telecommunications sector, are set up as desirable policy targets in their own right. And it is assumed that market mechanisms are required to achieve the developmental potential of the technology. For example, 'quality of learning' is taken to be the extent to which ICT is incorporated into education, and the privatization of telecommunications is identified as the main criterion for assessing network policy. However, at present there is little evidence that ICT contributes to better educational systems, even in industrialized societies, while there are studies showing that market mechanisms cannot be relied upon to provide telecommunications 
access for poor communities in remote areas of developing countries (Bhatnagar, 2003).

Porter et al. (2002b) in their Global Competitiveness Report 2001-2002 provide an analysis that differentiates the role of ICT for development in different socio-economic conditions within the global market. They present economic development as a process that moves successively through three general states based on national income levels. At the low-income level, economic growth is determined mainly by the mobilization of land, primary commodities and unskilled labour. At middle-income level, national economies get integrated into the international production system and economic growth is increasingly achieved by adopting foreign technologies in local production. Economies at the high-income level achieve global competitiveness through rapid technology innovation and high rates of learning, especially science-based learning.

In discussing these three states of development, Porter et al. (ibid.) suggest that technology innovation has little significance in low-income economies, for which the main challenge is to get the basic market factors of land, labour, and capital to work properly. The harnessing of 'global technologies' acquires greater importance as countries move from low to middle income. The institutional characteristics of the knowledge-based economies at the high-income level include continuous training and upgrading of the workforce, high labour mobility across enterprises, and a dynamic combination of fierce competition and cooperation among enterprises. Governments play a crucial role in the higher education, $R \& D$, and market regulation that supports start-ups and high-tech enterprises, while business firms become less hierarchical and form flexible buyer-supplier networks.

From this report's perspective, the role of ICT therefore varies according to the extent to which a country's market economy has developed the capacity to enter the global market and to sustain competitive advantage. The problem of pursuing the virtuous circle of ICT innovation and development in the global competitive market surfaces again here. The analysis of the role of ICT in terms of competitiveness does not explain how progression on the ranking scale occurs. The linearity of the model and the notion of competitiveness suggest that the more successful economies in the global market are more capable of technology innovation to enhance their economic gain and, thereby, to disadvantage those less techno-economically capable of doing so.

Indeed, the authors of the report note that the hardest transition along their three-stage model of development is from a technology-importing, efficiency-based 'middle' level economy to the innovation-based, highincome knowledge economy. They point out that the challenge for policy 
lies in the process of adaptation to new institutional conditions at the transition points of the model. This observation suggests the need to shift the study of the way ICT is associated with development from tracing the purely economic reasoning of the market to consideration of the social conditions that sustain it. What are the institutional conditions of the mutually reinforcing processes of ICT innovation and a growth-fostering competitive market?

The 2002 World Development Report of the World Bank elaborates on institutional conditions considered conducive to competitive economic action (World Bank, 2002). It explains a particular view of how institutions support markets: they channel information about market conditions, goods, and participants; they define property rights and enforcement mechanisms; and they increase competition in markets. Thus, state government is seen to be important for the regulation of property rights and their enforcement.

This report highlights the importance of the historical context of an economy and advises that new institutions should be built by complementing existing ones. Nevertheless, it provides clear direction towards 'good governance'. This is understood in a somewhat cyclical manner as the state provision of: institutions for the creation, protection, and enforcement of property rights; a regulatory regime to promote market competition; and sound macroeconomic policies that create a stable environment for market activity. In short, to the extent that social change is understood to be implicated in the dynamic intertwining of technology innovation and an effective market economy, the current discourse on development seeks to emulate the institutions of the few societies that have achieved the mobilization of ICT innovation to sustain economic growth through competitiveness in global markets.

However, this leads to the question of whether it is possible for developing countries around the world to emulate the human and institutional conditions of the few techno-economically advanced societies, and whether such emulation is an effective development strategy. I examine these questions in the following section by addressing the economic theory that underpins the views of market-driven development.

\section{CONTROVERSIES IN ECONOMIC THEORIES OF DEVELOPMENT}

The central concern preoccupying the four publications examined in the previous section focuses on how ICT can become an instrument for development in the context of the global market economy. This reflects the prevailing views in this domain and takes us to the core issue of 
development theory since the mid $20^{\text {th }}$ century: economic growth. However, these views are not uncontroversial. To understand better the limitations of these propositions on ICT and development, and the reasoning that seeks to justify them, I now examine the theoretical underpinnings of economic development and their related policy debates.

In a nutshell, the prevailing perception of the development problem focuses on how to establish efficient markets in societies that, for various historical reasons, have low production capacity, ineffective allocation of existing productive resources, and inadequate trade mechanisms. In neoclassical economic theory, economic growth rests on two fundamental assumptions: the rational behaviour of economic agents - individuals and business organizations - and the capacity of market competition to eliminate inefficient producers and to create equilibria of production and consumption at optimal conditions of full employment and the lowest consumer prices. From this view, development therefore consists of efforts to transform the socio-economic regimes that exist in different countries into such free markets. To achieve this, development policies are expected to include: abolishing protection of national industries from foreign competition and eliminating trade barriers, in particular barriers to the flow of capital; privatization of organizations governed by political control, such as telecommunications; and exploitation of natural resources, mainly oil and minerals. Governments following such policies assume the minimal regulatory role of overseeing the legal framework of property rights that is required for the free market.

Two serious problems arise when putting this theory into practice. First, the experience of applying these principles in Western economies has led to an understanding that the free market tends to run into crises, known as 'market failures'. Imbalances of production, prices, and consumption give rise to combinations of undesirable conditions, such as inflation and unemployment. The second problem is that although, arguably, the theory is the basis of economic performance of the few rich countries of the world, little is known about how it can be fostered in the countries that are currently poor.

The main challenge to the neo-classical economic perspective of development stems from the theory of new institutionalist economics (NIE). This assumes that the rational individual choice on which neo-classical theory is built is unrealistic because individuals rarely possess complete information about the market. As a result, economic transactions require the search for relevant information, with such a search entailing costs. In addition, economies involve negotiations and the establishment of contracts for minimizing risks; they also need mechanisms to enforce such contracts. Moreover, the rationality of individuals' decisions is biased by their 'mental 
models' (North, 1995), their culturally-formed values about the world. Collectively, these factors can lead to inefficient economies.

With these observations, NIE broadens the analysis of rational behaviour across cultural and political dimensions. It shifts attention to the significance of institutions, that is, the formal rules and informal conventions that govern the behaviour of economic actors - whether individuals or firms. Institutions are important because they limit the scope of search of economic choices, thereby reducing transaction costs. They also reduce uncertainty by providing enforcement mechanisms. While market competition remains the core mechanism for increasing efficiency, NIE shows economic and noneconomic institutions play a key role in shaping the economy. Indeed, the economic history of today's advanced economies shows the importance of government organizations in preventing and correcting market failure. A network of organizations standing watch over the market dynamics are ready to intervene, primarily in financial and capital markets, not only with regulatory capacity but also as economic actors in their own right. Moreover, state organizations play a significant role in shaping the political rules and social norms that drive, or at least influence, the decisions of economic actors.

In effect, NIE regards non-market institutions as mechanisms for overcoming the costs and risks of the market, thus serving the economic interests of rational individuals and firms. It provides both the grounds for an interventionist state and legitimacy for the involvement of multiple civic actors in the development effort, which are seen as necessary for providing support in the transition to an efficiently functioning, largely free-market economy. Moreover, NIE recognizes the diversity of mental models that are found in different cultures and implicated in economic behaviour and institutional arrangements. Policy possibilities depend on the institutional history of an economy. In the jargon of NIE, economic change is 'path dependent', in that it is constrained by the historically developed institutions of a society (Toye, 1995).

Policies of development in almost all countries demonstrate the influence of varying combinations of neo-classical and NIE theories. Many policy analysts, though, are critical of the prevalence of neo-classical ideas in the policy recommendations of the most powerful international development agencies. For instance, Stiglitz voices strong criticisms of the policies of the International Monetary Fund (IMF) and US Treasury - what he calls the new 'Washington Consensus' about the 'right' policies for developing countries - because they are based on the orthodoxy of the neo-classical economic prescription of economic restructuring towards a global free market regime with unrestricted trade and capital flows (Stiglitz, 2002). This kind of policy, he argues, does not target the poor who are only marginal in the 
underdeveloped markets; the expectation is that the incorporation of developing countries into the global free market will have 'trickle-down' beneficial effects for their poor populations. Stiglitz's critique emphasizes the importance of building institutions for the free market along locallymeaningful routes, such as the World Bank's advice to establish a competitive banking system and a legal system able to enforce contracts (World Bank, 2002).

Stiglitz (ibid.) goes even further than suggesting the importance of developing institutions for the market. He is critical of policies that aim to reduce the role of government in developing countries as he argues that strong and effective government, rather than less government, is required for the transition to effective markets. He looks at the course of development during the 1990s of different countries, some of which followed the development prescriptions of the IMF while others resisted these pressures by implementing policies and taking action they considered locally appropriate. He cites China, Malaysia and Poland among the developing countries that have done better in raising their populations above poverty, avoiding crises, and coping with international economic crises. He argues that their governments have succeeded by seeking to change towards freemarket regimes through a careful sequencing of the opening of the economy to the building of necessary institutions and by the pursuit of 'homegrown' policies sensitive to the specific needs and concerns of the country.

Other critics of neo-classical economic theory highlight the significance of politics in the development process (Bates, 1995; Leftwich, 2000). The basic premise here is that the assumption of rational choice for the economic actor is complicated by a diversity of interests, preferences, values, and ideas. Thus, economic behaviour - basically the use, production, and distribution of resources - involves activities of conflict, cooperation, and negotiation. This consideration of politics alters significantly the understanding of the market-led development process in at least two ways. First, it highlights the centrality of state government in shaping the course of development. Second, it reinforces the contextual, historically contingent nature of a society's development process.

Evidence for the validity of such an understanding of the development process comes from the history of the so-called 'developmental states' clustered in East and South East Asia: South Korea, Taiwan, Singapore, China, Indonesia, Thailand, and Malaysia (Wade, 1990). These are the very few countries that managed to achieve average annual GNP per capita growth rates in excess of $4 \%$ between 1965 and 1997. Governments in all these countries had a much more prominent interventionist role in the economy than suggested by neo-classical economic theory and most versions of the NIE. For instance, the economic growth of Taiwan, South 
Korea, and Japan in the 1980s shows that the governments of these countries used state power heavily to manage the market (Wade, ibid.). This included raising surplus for investment, ensuring that a high proportion of this was invested in productive capacity within the country and in industries that would yield higher wages in the future, and exposing investment projects to international competition.

Studies of technology innovation in the developmental states have also recognized the significance of interventionist government policies in fostering high-tech industries, as well as in steering technology innovation across industries (Freeman, 1987; Hobday, 1995; Archibugi and Michie, 1997). However, it is important to note that studies of this region have not resulted in alternative universal theories of development, or general models of techno-economic action. In looking at the way Korea, Taiwan, Singapore and Hong Kong achieved innovation-driven growth, Hobday (1995: p.4) notes that '(h)ighlighting the plurality of government policies and development models within the region, the study shows that there was no single path to development, nor any single model or lesson for other developing countries'. The main conclusion towards which such studies converge is the broad observation that the political institutions of the developmental states diverge from those associated with successful economies in western democracies.

The position outlined above can be summarized as suggesting economic development is a situated, context-specific process that is entangled with indigenous politics and historically-formed institutions. This echoes Granovetter's (1985) thesis of economic action embedded in social structures; his critique of economics as an under-socialized conception of rational action is particularly relevant here. In this light, it is not surprising that ICT does not serve all societies equally well as a tool for development. Therefore, although universalist models of rational economic behaviour may offer useful working hypotheses, the social relations within which economic action is embedded may drastically change the scope of desirable, feasible and therefore rational - action.

\section{CONCLUSION}

The static picture of ICT and development measures presented in the tables of development indicators assembled by international development agencies makes a strong association between ICT and development: the more successful economies have more technologies and are better prepared for using them to their competitive advantage. This paper's brief discussion 
of four such publications has shown that this association tends to be interpreted as indicating that ICT is an instrument for development.

However, if we consider the dynamics of ICT and development, that is, if we consider ICT innovation and development as processes rather than as states exemplified by existing societies, the close correlation between ICT innovation capabilities and success in the market tells a different story. It shows that a few economies have historically developed an institutional setting that sustains the mutual re-enforcing of competent free-market economic activity and ICT innovation, but that such a process has not been set in motion in developing countries. Yet, developing countries are now advised to simultaneously: acquire the ICTs that served the advanced market economies well; emulate their institutions; and engage in innovation-driven free market competition. This is an unrealistic expectation because, as the critics of neo-classical economic theory and policy have pointed out, economic and institutional change is a path-dependent, historicallycontingent process. Thus, ICT continues to be a factor responsible for the widening of the huge difference between the rich and the poor societies measured along the multiple linear scales of progress in the global market economy.

This argument does not suggest that ICT is inappropriate for developing countries, but it does indicate the misguided nature of the universalist visions of economic and institutional development that currently accompany efforts to promote the diffusion of the technology. These visions frustrate efforts to make sense of locally meaningful ways of accommodating ICTs in socioeconomic activities. They prescribe what ICT is used for and restrict the scope for the improvisation that is necessary for making technology a trusted actor amidst the negotiations which bring about effective courses of action for change in industry or government.

Information systems professionals in developing countries have for several decades been called on to support the transfer of business practice that has been considered to be effective in the successfully competitive economies, such as business process re-engineering, integrated enterprise information infrastructures, or customer relationship management systems. More recently, they have been channeling their professional skills into egovernment projects, which has involved them in intervening in the explicitly political setting of government administration. There is a widespread expectation that government can be transformed into a network of rationalized institutions, as seen desirable from an acontextual view of economic development.

It is important that information systems professionals in developing countries should be aware that this view is controversial in economic theory and policy, and that there is hardly any evidence to date that it delivers its 
promised results of entering a virtuous techno-economic circle. As emulation of western organizational practices in developing countries has rarely succeeded, the pleas in information systems literature for situated action appropriate to formative contexts have taken on a particular poignancy.

\section{REFERENCES}

Archibugi, D. and Michie, J. "Technological Globalisation and National Systems of Innovation: An Introduction", in Technology, Globalisation and Economic Performance, D. Archibugi and J. Michie, Cambridge: Cambridge University Press, 1997, pp. 1-23.

Avgerou, C. Information Systems and Global Diversity, Oxford: Oxford University Press, 2002a.

Avgerou, C. "IT as an Institutional Actor in Developing Countries", in Information \& Communication Technologies and Development: New Opportunities, Perspectives \& Challenges, S. Krishna, and S. Madon (eds.), proceedings of $7^{\text {th }}$ International Working Conference of IFIP WG 9.4, Bangalore: Indian Institute of Management Bangalore, 29-31 May, 2002b.

Avgerou, C. and Walsham G. (eds.) Information Technology in Context: Studies from the Perspective of Developing Countries, London: Ashgate, 2000.

Bates, R. H. "Social Dilemmas and Rational Individuals: An Assessment of the New Institutionalism", in The New Institutional Economics and Third World Development, J. Harriss, J. Hunter, and C. M. Lewis, London: Routledge, 1995, pp. 27-48.

Best, M. L. and Maclay, C. M. "Community Internet access in rural areas: solving the economic sustainability puzzle", in The Global Information Technology Report: Readiness for the Networked World, G. S. Kirkman, P. K. Cornelius, J. D. Sachs, and K. Schwab, Oxford: Oxford University Press, 2002, pp. 76-89.

Bhatnagar, S. "Development and Telecom Access: Cases from South Asia", in Information Systems and the Economics of Innovation, C. Avgerou and R. L. La Rovere (eds.), Cheltenham, UK: Edward Elgar, 2003.

Bhatnagar, S. C. and Bjorn-Andersen, N. (eds.) Information Technology in Developing Countries, Amsterdam: North-Holland, 1990.

Bhatnagar, S. C. and Odedra, M. (eds.) Social Implications of Computers in Developing Countries, New Delhi: Tata McGraw-Hill, 1992.

Ciborra, C. and Lanzara, G. F. "Formative Contexts and Information Technology: Understanding the Dynamics of Innovation in Organizations", Accounting, Management and Information Technology, (4:2), 1994, pp. 61-86.

Eggleston, K., R. Jensen, and Zeckhauser, R. "Information and Communication Technologies, Markets, and Economic Development", in The Global Information Technology Report: Readiness for the Networked World, G. S. Kirkman, P. K. Cornelius, J. D. Sachs and K. Schwab, New York: Oxford University Press, 2002, pp. 62-75.

Freeman, C. "Technology Policy and Economic Performance", Cambridge Journal of Economics, (18), 463-514, 1987.

Granovetter, M. "Economic Action and Social Structure: The Problem of Embeddedness", American Journal of Sociology, (91:3), 1985, pp. 481-510.

Hobday, M. Innovation in East Asia: The Challenge to Japan, Cheltenham, UK: Edward Elgar, 1995. 
Kirkman, G. S., Cornelius P. K., Sachs J. D., and Schwab K. The Global Information Technology Report 2001-2002: Readiness for the Networked World, New York: Oxford University Press, 2002.

Krishna, S. and Madon, S. Information \& Communication Technologies and Development: New Opportunities, Perspectives \& Challenges, Proceedings of $7^{\text {th }}$ International Working Conference of IFIP WG 9.4, Bangalore: Indian Institute of Management Bangalore, 29-31 May, 2002.

Leftwich, A. States of Development: On the Primacy of Politics in Development, Cambridge: Polity, 2000.

North, D. C. "The New Institutional Economics and Third World Development", in The New Institutional Economics and Third World Development, J. Harriss, J. Hunter, and C. M. Lewis (eds.), London: Routledge, 1995, pp. 17-26.

Odedra-Straub, M. (ed.) Global Information Technology and Socio-Economic Development, Nashua, New Hampshire: Ivy League, 1996.

Porter, M. E., Sachs, J. D., Cornelius, P. K., McArthur J. W., and Schwab K. The Global Competitiveness Report 2001-2002, New York: Oxford University Press, 2002a.

Porter, M. E., Sachs, J. D., Cornelius, P. K., McArthur J. W., and Schwab K. "Executive Summary: Competitiveness and Stages of Economic Development", in The Global Competitiveness Report 2001-2002, M. E. Porter, J. D. Sachs, P. K. Cornelius, J. W. McArthur and K. Schwab, New York: Oxford University Press, 2002b, pp. 16-25.

Preker, A., Bos, E., Wang, J., Peabody, J., and Jamison, D. T. Measuring Country Performance on Health, Washington, DC: World Bank, 1999.

Sahay, S. Information Flows, Local Improvisations and Work Practices, Proceedings of $6^{\text {th }}$ International Working Conference of IFIP WG 9.4, Cape Town, 24-26 May, 2000.

Stiglitz, J. Globalization and its Discontents, London, Penguin, 2002

Suchman, L. Plans and Situated Action, Cambridge: Cambridge University Press, 1987.

Toye, J. "The New Institutional Economics and its Implications for Development Theory", in The New Institutional Economics and Third World Development, J. Harriss, J. Hunter and C. M. Lewis, London: Routledge, 1995, pp. 49-70.

United Nations Development Programme. Making New Technologies Work for Human Development, New York: UNDP, 2001.

Wade, R. Governing the Market: Economic Theory and the Role of Government in East Asian Industrialization, Princeton, New Jersey: Princeton University Press, 1990.

World Bank Building Institutions for Markets, New York: Oxford University Press, 2002.

\section{About the Author}

Chrisanthi Avgerou (C.Avgerou@lse.ac.uk) is Senior Lecturer in Information Systems at the London School of Economics. She holds a degree in Mathematics from Athens University, an MSc in Computer Studies from Loughborough University and a Ph.D. in Information Systems from the London School of Economics. Dr. Avgerou teaches information systems implementation and information systems in developing countries. She chaired the IFIP WG 9.4 group from 1996 to 2003; since 1999 she has been vice-chairperson of the IFIP Technical Committee 9. Her research interests include the relationship of information technology to organisational change, and the role of IT in socio-economic development. 